\title{
RILEVAZIONE DI VIRUS RESPIRATORI IN PAZIENTI CON PATOLOGIE DEL TRATTO RESPIRATORIO INFERIORE
}

\author{
SelleriM.', Minosse C.', Zaniratti M.S.', Cappiello G. ${ }^{2}$ \\ Lauria F.N. ${ }^{3}$, Longo R.' ${ }^{2}$ Roselli P. ${ }^{3}$, Antonelli S. ${ }^{3}$, SchifanoE.', \\ Tana M.', Visca M.', Cava M. ${ }^{2}$, Spanò A. ${ }^{2}$, De Mori P.', \\ Gualano G.', Capobianchi M.R.', PuroV.' \\ 'INMI "L. Spallanzani", Roma; \\ ${ }^{2}$ Ospedale Sandro Pertini, Roma; \\ ${ }^{3}$ Ospedale Civile di Vasto, Vasto
}

\section{Introduzione:}

Non esistono molte evidenze relative al coinvolgimento di virus nelle patologie delle basse vie respiratorie. Abbiamo valutato la prevalenza dei virus respiratori in 184 campioni di espettorato o aspirato endotracheale, raccolti consecutivamente da pazienti ricoverati con patologie respiratorie (aprile 2004-febbraio 2005), e analizzato l'eventuale associazione con broncopatia cronica ostruttiva (BPCO).

Metodi:

I campioni sono stati analizzati tramite PCR o RT-PCR per i seguenti virus: adenovirus (ADV), influenza A e B, MPV, parainfluenza (PIV)-1,2 e 3, respiratorio sinciziale (RSV), RV, ed i coronavirus umani OC43, 229E, NL63. Oltre ai normali test microbiologici, è stata eseguita anche la ricerca, mediante PCR, di Clamydia pneumoniae, Mycoplasma pneumoniae e Legionella pneumophila. Gli espettorati sono stati validati mediante conta dei polimorfonucleati (requisito minimo: 25 cellule per campo).

\section{Risultati:}

Il $38,6 \%$ dei pazienti presentavano BPCO all'anamnesi, mentre e il $20.6 \%$ erano ricoverati in terapia intensiva. I virus più frequentemente riscontrati risultavano rhinovirus (RV, $44.0 \%$, di cui $1^{\prime} 7.4 \%$ in associazione con altri virus), PIV-1 ed NL63 (entrambi $2.7 \%$, di cui il $40 \%$ associati ad altri virus). ADV, influenza A e RSV sono stati rilevati ciascuno in un solo campione, gli ultimi due associati con RV. La prevalenza dei RV è risultata significativamente più elevata nei pazienti con BPCO.

\section{Conclusioni:}

Lo studio mostra una prevalenza inaspettatamente elevata di RV nei campioni respiratori profondi ottenuti da pazienti adulti, concordando con recenti segnalazioni riguardanti il tratto respiratorio superiore di pazienti pediatrici ed adulti, e suggerisce che questi virus possano infettare anche il tratto respiratorio inferiore. Dai dati emerge una significativa associazione con BPCO, sia in anamnesi, sia in fase di riacutizzazione, ed indipendentemente dal trattamento in terapia intensiva. Sono necessari studi più ampi per valutare l'eventuale ruolo eziologico dei RV, e l'eventuale associazione con il decorso clinico.

Ricerca Finalizzata, convenzione BS3.118 